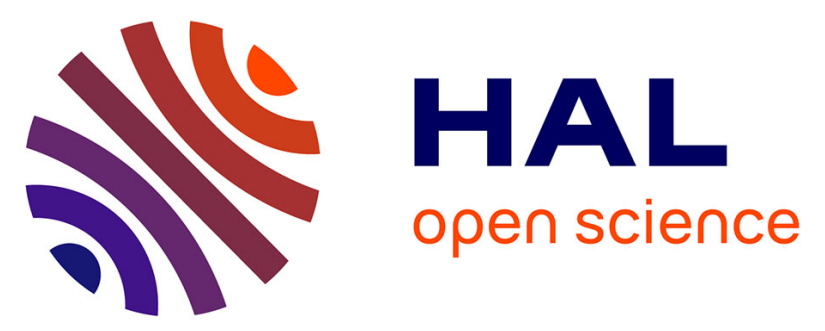

\title{
Association of the CBLB gene with MS: new evidence from a replication study in an Italian population
} Lucia Corrado, Laura Bergamaschi, Nadia Barizzone, Maria Edvige Fasano, Franca Rosa Guerini, Marco Salvetti, Daniela Galimberti, Maria Donata Benedetti, Maurizio Leone, Sandra d'Alfonso

\section{To cite this version:}

Lucia Corrado, Laura Bergamaschi, Nadia Barizzone, Maria Edvige Fasano, Franca Rosa Guerini, et al.. Association of the CBLB gene with MS: new evidence from a replication study in an Italian population. Journal of Medical Genetics, 2010, 48 (3), pp.210. 10.1136/jmg.2010.081380 . hal00581008

\section{HAL Id: hal-00581008 \\ https://hal.science/hal-00581008}

Submitted on 30 Mar 2011

HAL is a multi-disciplinary open access archive for the deposit and dissemination of scientific research documents, whether they are published or not. The documents may come from teaching and research institutions in France or abroad, or from public or private research centers.
L'archive ouverte pluridisciplinaire $\mathbf{H A L}$, est destinée au dépôt et à la diffusion de documents scientifiques de niveau recherche, publiés ou non, émanant des établissements d'enseignement et de recherche français ou étrangers, des laboratoires publics ou privés. 


\section{Association of the $C B L B$ gene with MS: new evidence from a replication study in an Italian}

\section{population}

Lucia Corrado $^{1}$, Laura Bergamaschi ${ }^{1}$, Nadia Barizzone ${ }^{1}$, Maria Edvige Fasano ${ }^{2}$, Franca R Guerini ${ }^{3}$, Marco Salvetti $^{4}$, Daniela Galimberti ${ }^{5}$, Maria Donata Benedetti ${ }^{6}$, Maurizio Leone ${ }^{7}$, Sandra D' Alfonso ${ }^{1}$

${ }^{1}$ Department of Medical Sciences and Interdisciplinary Research Center of Autoimmune Diseases (IRCAD), University of Eastern Piedmont, Novara, Italy

${ }^{2}$ SCDU Transplantation Immunology, A.O.U. S. Giovanni Battista di Torino, Turin, Italy

${ }^{3}$ Laboratory of Molecular Medicine and Biotechnologies, Don C. Gnocchi Foundation IRCCS, S. Maria Nascente, Milan, Italy

${ }^{4}$ Neurology and Center for Experimental Neurological Therapy (CENTERS), Università La Sapienza, Rome, Italy

${ }^{5}$ Università di Milano, Fondazione Cà Granda, IRCCS Ospedale Maggiore Policlinico, Milan , Italy

${ }^{6}$ Section of Neurology, Department of Neurological and Vision Sciences, University of Verona, Policlinico G. Rossi, Verona, Italy

${ }^{7}$ Department of Neurology, A.O.U. Maggiore della Carità, and IRCAD, Novara, Italy

Keywords: CBLB gene, Multiple Sclerosis, rs9657904, replication study

Words count: 995 words

Corresponding author:

Sandra D'Alfonso

Department of Medical Sciences

Eastern Piedmont University

Via Solaroli 17

28100 Novara, Italy

Telephone: 39321 660606, Fax: 39321620421

Email: dalfonso@med.unipmn.it 


\begin{abstract}
Background The T allele of rs9657904 within the $C B L B$ gene was recently found to be significantly associated with multiple sclerosis (MS) in a genome-wide association study (GWAS) in Sardinia. Objective To replicate this association in an independent population with a different genetic background. Methods We typed the rs9657904 variant in a sample of 1435 cases and 1466 controls from the Italian mainland. Results We found that also in this sample, the common allele $\mathrm{T}$ of rs9657904 is significantly positively associated (one tailed $\mathrm{p}=7.35 \times 10^{-5}$ ) and with a comparable effect size with $\mathrm{MS}(\mathrm{OR}=1.31,95 \% \mathrm{CI}: 1.14-1.52)$. Conclusion These data provide further evidence of MS disease association with variation within $C B L B$.
\end{abstract}




\section{Introduction}

Multiple sclerosis (MS) is a multifactorial neuroinflammatory and autoimmune disorder characterized by a progressive demyelination of axons of the central nervous system (CNS) and neuronal cell degeneration, resulting in a severe disabling condition. Interactions between unknown environmental factors and alleles of many susceptibility loci across the genome contribute together to the development of the disease. [1] Until recently, the only genes consistently associated with MS mapped to the human Major Histocompatibility Complex (MHC) or HLA (Human Leukocyte Antigens) region.

The study of the genetics of MS, after years of difficulty, is undergoing a period of rapid development. This is due to the use of large datasets as well as improved genotyping techniques that have allowed the first genome wide association scans (GWAS).[2-6] Once those significant associations are replicated in different populations, they acquire a profound importance for disease understanding and for focusing lines of investigation for functional and bioinformatics analysis.[7,8]

Thus far, the major GWAS findings have come from analyses of populations with northern European origin in which MS is particularly common. Recently, a novel association with risk for MS of some markers within the $C B L B$ gene (Cas-Br-M (murine) ecotropic retroviral transforming sequence b, 3q13.11) was observed in the island population from Sardinia.[6] To assess the associated variant in an independent sample set from the Italian mainland is cogent for several reasons. First of all, while sharing a very similar environment with much of continental Italy, Sardinians are, by most measures, genetically different from continental Italians, although to a lesser extent than populations from Northern Europe.[9] Furthermore, Sardinia has at least 3 times higher MS prevalence than the Italian mainland. [10] Also, the main genetic risk factor for MS at the HLA class II DRB1-DQB1 loci shows a very different allelic distribution in Italy versus Sardinia. In the Sardinian population, the HLA association is mainly accounted for the $H L A-D R B 1 * 03: 01$ allele,[11] included within an extended or ancestral HLA haplotype, namely $H L A-A * 30, B * 18, C w * 5, D R B 1 * 03: 01$, that is very rare elsewhere.

Conversely, in continental Italy the MS association, as in most other populations, is marked by the 
$H L A-D R B 1 * 15: 01$ allele.[12]

Hence we tested the positive association observed with the $\mathrm{T}$ allele of the top associated variant (rs9657904) observed in the Sardinian study in a large cohort of continental MS patients and controls. 


\section{Patients and Methods}

The SNP rs9657904 C>T in intron 1 of the $C B L B$ gene was genotyped in 1435 MS cases and 1466 regionally matched controls from continental Northern-Central Italy.

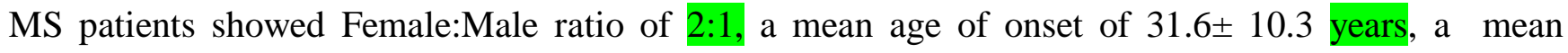
Expanded Disability Status Scale (EDSS) $3.10 \pm 2.23$ and a mean Multiple Sclerosis Severity Score (MSSS) 3.91 $\pm 2.72 .[13]$ Ninety percent of the patients presented a Relapsing Remitting while $10 \%$ a Primary Progressive disease course. The controls (Female: Male 1.3:1) were blood donors who shared the same ethnicity background of cases. Individuals with Sardinian origin were selectively excluded. All the samples were collected after informed consent and appropriate ethical approvals.

Genotyping was performed with a Taqman genotyping assay (Assay ID C_1499397_10, Applied Biosystems). The genotype success rate of this Taqman assay was $97 \%$.

The statistical significance of the difference of allele and genotype frequencies between MS patients and controls was evaluated using the $\chi^{2}$ test with Yates' correction. The strength of association was evaluated by Odds ratio (OR) and its 95\% confidence intervals (95\% C.I.). 


\section{Results and Discussion}

The same allele (T) of rs9657904 SNP, positively associated with MS in Sardinian population, was significantly associated with MS risk (one tailed $\mathrm{p}=7.35 \times 10^{-5}$ ), and even showed a comparable effect size $(\mathrm{OR}=1.31)$ also in the Italian mainland (Table 1$)$.

The genotype frequencies did not deviate from Hardy-Weinberg equilibrium either in cases $(p=0.39)$ and controls $(\mathrm{p}=0.19)$. The association of the $\mathrm{T}$ allele seems to be consistent with a recessive model, since it shows a significant increase in MS patients only in homozygosis (Table 1). Moreover, no significant interaction was detected in a case-only analysis with $H L A-D R B 1 * 15: 01$ allele, with no difference of allele frequencies between $H L A-D R B 1 * 15: 01$ positive $(\mathrm{n}=361)$ and negative $(\mathrm{n}=825)$ patients (Minor Allele Frequency: 0.15 vs $0.14 \mathrm{p}=0.67$ ). This is consistent with the reported lack of interaction with $H L A-D R B 1 * 03: 01$ in the Sardinian study [5] and indicates that the same $C B L B$ variant is associated with MS in two populations with distinct HLA associations. Moreover, the associated variant exhibits nearly overlapping frequencies in Sardinia [5] and in the Italian mainland; it is thus unlikely that variation at $C B L B$ explains the higher disease prevalence observed in Sardinia.

Conversely, $C B L B$ gene does not appear in the list of MS associated loci that satisfy the genome-wide significance threshold from previous GWAS, despite this SNP is tagged $\left(r^{2} \geq 0.9\right)$ by at least one SNP in the different platforms utilized so far.[1,2-4] This could suggest that in these populations, mainly from northern European origin, rs9657904 SNP shows a weaker association with MS. This observation can support the hypothesis that the tested SNP in $C B L B$ gene is not the primarily associated variant and may indicate that the linkage disequilibrium structure of populations from southern Europe might favor the detection of this association.

Since the disease association might be affected by many variables, in particular by the linkage disequilibrium between marker allele and causal allele, further cross-population comparisons using samples from more distantly related populations along with additional re-sequencing/fine mapping 
work appear necessary to reduce the MS association to its essential, potentially causal elements. 
Table 1: Association results of $C B L B$ rs9657904

\begin{tabular}{lllll}
\hline \multicolumn{1}{c}{} & $\begin{array}{l}\text { Cases } \\
\mathrm{N}(\%)\end{array}$ & $\begin{array}{c}\text { Controls } \\
\mathrm{N}(\%)\end{array}$ & OR (95\% C.I.) \\
\hline \multicolumn{1}{l}{ Genotype } & & & & \\
& $\mathrm{TT}$ & $1054(73.4)$ & $974(66.4)$ & $1.40(1.19-1.64)$ \\
& $\mathrm{TC}$ & $347(24.2)$ & $451(30.8)$ & $0.72(0.61-0.85)$ \\
& $\mathrm{CC}$ & $34(2.4)$ & $41(2.8)$ & $0.84(0.52-1.37)$ \\
Allele & & & & \\
& $\mathrm{T}$ & $2455(85.5)$ & $2399(81.8)$ & $1.31(1.14-1.52)$ \\
& $\mathrm{C}$ & $415(14.5)$ & $533(18.2)$ & \\
\hline
\end{tabular}

Notes to Table 1:

The frequency of the T allele was significantly increased in the patients (one tailed $\mathrm{p}=7.35 \times 10^{-5}$ )

$\mathrm{N}$ indicates the number of individuals or alleles

OR: Odds ratio

95\% C.I: $95 \%$ confidence intervals 


\section{Acknowledgments}

This work was supported by: the Italian Foundation for Multiple Sclerosis (FISM grants 2001/R/44, 2002/R/40 and 2005/R/10, 2008/R/11); Regione Piemonte Ricerca Sanitaria Finalizzata (grants 2003 2004, 2007, 2008, 2009), Italian MIUR Ministry (PRIN 2008), Eastern Piedmont University, Compagnia di San Paolo (Turin), Fondazione CRT (Turin). DG was supported by Italian Ministry of Health "Progetto Giovani Ricercatori 2008”.

NB and LC were supported by a fellowship from FISM (2003/B/2, 2009/B/1). L.B. was supported by a PhD Lagrange Fellowship. We are grateful to the patients and their parents.

We are grateful to Prof. Francesco Cucca for helpful discussions and to Dr Elizabeth Grass for editing the manuscript.

\section{Competing financial interests}

The authors declare no competing financial interests.

\section{Copyright licence statement}

The Corresponding Author has the right to grant on behalf of all authors and does grant on behalf of all authors, an exclusive licence (or non-exclusive for government employees) on a worldwide basis to the BMJ Publishing Group Ltd and its Licensees to permit this article (if accepted) to be published in Journal of Medical Genetics and any other BMJPGL products to exploit all subsidiary rights, as set out in our licence (http://group.bmj.com/products/journals/instructions-for-authors/licence-forms). 


\section{References}

1. Compston A, Sadovnick AD. Epidemiology and genetics of multiple sclerosis. Curr Opin Neurol Neurosurg. 1992;5:175-81.

2. Australia and New Zealand Multiple Sclerosis Genetics Consortium (ANZgene). Nat. Genet. $2009 ; .41: 824-828$

3. De Jager PL, Jia X, Wang J, de Bakker PI, Ottoboni L, Aggarwal NT, Piccio L, Raychaudhuri S, Tran D, Aubin C, Briskin R, Romano S; International MS Genetics Consortium, Baranzini SE, McCauley JL, Pericak-Vance MA, Haines JL, Gibson RA, Naeglin Y, Uitdehaag B, Matthews PM, Kappos L, Polman C, McArdle WL, Strachan DP, Evans D, Cross AH, Daly MJ, Compston A, Sawcer SJ, Weiner HL, Hauser SL, Hafler DA, Oksenberg JR. Nat. Genet. 2009; 41:776-782

4. International Multiple Sclerosis Genetics Consortium (IMSGC). N. Engl. J. Med. 2007;357:851-862

5. Baranzini SE, Wang J, Gibson RA, Galwey N, Naegelin Y, Barkhof F, Radue EW, Lindberg RL, Uitdehaag BM, Johnson MR, Angelakopoulou A, Hall L, Richardson JC, Prinjha RK, Gass A, Geurts JJ, Kragt J, Sombekke M, Vrenken H, Qualley P, Lincoln RR, Gomez R, Caillier SJ, George MF, Mousavi H, Guerrero R, Okuda DT, Cree BA, Green AJ, Waubant E, Goodin DS, Pelletier D, Matthews PM, Hauser SL, Kappos L, Polman CH, Oksenberg JR. Hum. Mol. Genet. 2009;18:767-78

6. Sanna S, Pitzalis M, Zoledziewska M, Zara I, Sidore C, Murru R, Whalen MB, Busonero F, Maschio A, Costa G, Melis MC, Deidda F, Poddie F, Morelli L, Farina G, Li Y, Dei M, Lai S, Mulas A, Cuccuru G, Porcu E, Liang L, Zavattari P, Moi L, Deriu E, Urru MF, Bajorek M, Satta MA, Cocco E, Ferrigno P, Sotgiu S, Pugliatti M, Traccis S, Angius A, Melis M, Rosati G, Abecasis GR, Uda M, Marrosu MG, Schlessinger D, Cucca F. Nat. Genet, 2010; 42:495-7

7. Liu DV, Maier LM, Hafler DA, Wittrup KD J. Immunother. 2009; 32:887-94

8. Baranzini SE, Galwey NW, Wang J, Khankhanian P, Lindberg R, Pelletier D, Wu W, Uitdehaag 
BM, Kappos L; GeneMSA Consortium, Polman CH, Matthews PM, Hauser SL, Gibson RA, Oksenberg JR, Barnes MR. Hum. Mol. Genet. 2009;18:2078-90

9. Lampis R, Morelli L, Congia M, Macis MD, Mulargia A, Loddo M, De Virgiliis S, Marrosu MG, Todd JA, Cucca F..Hum. Mol. Genet. 2000; 9:2959-2965

10. Pugliatti M, Rosati G, Carton H, Riise T, Drulovic J, Vécsei L, Milanov I.. Eur. J. Neurol. $2006 ; 13: 700-722$

11. Marrosu MG, Murru R, Murru MR, Costa G, Zavattari P, Whalen M, Cocco E, Mancosu C, Schirru L, Solla E, Fadda E, Melis C, Porru I, Rolesu M, Cucca F.Hum. Mol. Genet. 2001;10:2907-2916

12. Ballerini C, Guerini FR, Rombolà G, Rosati E, Massacesi L, Ferrante P, Caputo D, Talamanca LF, Naldi P, Liguori M, Alizadeh M, Momigliano-Richiardi P, D'Alfonso S. Neuroimmunol. 2004;150: 178-85

13. Roxburgh RH, Seaman SR, Masterman T, Hensiek AE, Sawcer SJ, Vukusic S, Achiti I, Confavreux C, Coustans M, le Page E, Edan G, McDonnell GV, Hawkins S, Trojano M, Liguori M, Cocco E, Marrosu MG, Tesser F, Leone MA, Weber A, Zipp F, Miterski B, Epplen JT, Oturai A, Sørensen PS, Celius EG, Lara NT, Montalban X, Villoslada P, Silva AM, Marta M, Leite I, Dubois B, Rubio J, Butzkueven H, Kilpatrick T, Mycko MP, Selmaj KW, Rio ME, Sá M, Salemi G, Savettieri G, Hillert J, Compston DA. Multiple Sclerosis Severity Score: using disability and disease duration to rate disease severity. Neurology. 2005;64:1144-51. 